Doi: $\underline{10.31578 / j e b s . v 5 i 1.194}$

\title{
Instructional Needs Assessment of Physics Teachers in the Teaching of Physics and Physics Practical in Ogun State Secondary Schools, Nigeria
}

\author{
Oludipe Bimbola Dupe*
}

\begin{abstract}
The study assessed the perceived instructional needs of physics teachers in the teaching of physics in secondary schools in Ogunstate, Nigeria. The study was a descriptive survey type of research. The sample was made up of eighty (80) physics teachers randomly drawn from forty-three (43) public Senior Secondary Schools in Abeokuta North, Abeokuta South and Ado Odo Ota Local Government areas of Ogun State. Data were collected by means of an Instructional Needs Inventory which consisted of 20 items on a 4-point Likert scale to which the teachers were required to indicate the extent of their instructional needs in Physics: "No help needed", "Little Help Needed", "Moderate Help needed" and "Much Help Needed". The inventory was pretested on a pilot sample of 30 Physics teachers in ljebu North and ljebu-Ode Local Government areas of Ogun State. The Cronbach coefficient alpha value was found to be 0.88 . One research question was posed and three hypotheses were tested at the 0.05 level of significance. The findings revealed that teachers need more help in developing questions that demand higher-order thinking skills; harnessing students' existing ideas and conceptions; encouraging students participation in classroom lessons; connecting science concepts to real life examples; conceptual understanding of physics concepts; adapting teaching methods to meet individual students' needs; linking students' ideas, values and beliefs to their classroom experiences; engaging students in problem-solving activities; creating innovative ideas that can foster learning; improvising instructional materials; helping students to ask questions and discuss their learning experiences; presenting science experiences as enjoyable, interesting and relevant; helping students to plan and carry out investigation in the laboratory; helping students to learn by discovery and teaching science process skills. However, the research revealed that teachers need little help in measuring students' conceptual understanding, helping students to interact actively with learning materials, using technology to enhance classroom experiences, assisting students to formulate their own questions, evaluating students' learning and helping students to connect practical with underlying theoretical concepts. The results also revealed that the instructional needs of physics teachers were not significantly sensitive to gender differences, experiences and professionalism of teachers.
\end{abstract}

Keywords: Instructional needs, physics teachers, teaching, physics practical, senior secondary schools, Ogun State

\section{Introduction}

Physics is the study of matter, energy and their interactions. It is the most basic of all sciences. It plays significant roles in advancement in technology. In fact, it generates the basic knowledge required for technological growth that will continue to propel advancement in Global economy. As important as physics is, researchers (Ajileye, 2006; Aina \& Akintunde, 2013; Oludipe,

\footnotetext{
* Science and Technology Education Department (STED), Faculty of Education, Olabisi Onabanjo University, Ago-Iwoye, Ogun State, Nigeria Correcponding Email: bimbola.oludipe@oouagoiwoye.edu.ng
} 
2009; Oludipe, 2013) have revealed that students in Nigeria underachieve in it both at internal and external examinations at the secondary school level. Poor teaching methods, overcrowded classrooms, insufficient laboratory facilities, the abstract nature of physics, poor numerical ability, overloaded physics syllabus and poor qualification of teachers are some of the factors attributing to poor performance in physics.

The physics teacher is very important for students' learning of the subject. S/he is the rallying point and her/his mastery of the content and good delivery is very important to how students learn physics. No wonder that the Federal Government of Nigeria (2014) in its National Policy of Education states that "no nation can rise above the quality of its educational system and no educational system can rise above the quality of its teachers". It is logical to assume that the quality of teaching determines the quality of students' learning. Quality teaching according to Snow-Renner and Lavier (2005), as well as Okafor (2007), lies at the teachers' capacity to transform written knowledge into forms that are pedagogically powerful and yet adaptive to students' abilities and backgrounds. However, it has been reported (Apata, 2007, Wenglinsky \& Silverstein, 2006; Oludipe, 2008, 2013) that physics teachers often lack the ability to communicate physics effectively, have low conceptual understanding of the subject, lack creative ability and poorly evaluate students' learning. This suggests that physics teachers have instructional needs and it becomes imperative to assess these needs in Nigerian secondary schools in order to inadvertently address the problem of poor performance in physics. Literature has been scanty in this stead and the available studies have not come to clear conclusions. The assessment of these needs will help to identify the problems encountered by teachers in providing meaningful instruction in the physics classroom. It will help to identify the gap(s) between the current and desired situations in physics teaching and learning.

\subsection{Research question}

1. What are the instructional needs of physics teachers in the teaching of physics in secondary schools?

\subsection{Hypotheses}

1. There is no significant difference in the perceived instructional needs of the physics teachers based on gender.

2. There is no significant difference in the instructional needs of physics teachers based on experience.

3. There is no significant difference in the instructional needs of physics teachers based on professional qualification.

\section{Methodology}

\subsection{Subject}

This study is a descriptive survey type of research. The sample was made up of eighty (80) physics teachers randomly drawn from forty-three (43) public senior secondary schools in Abeokuta North, Abeokuta South and Ado Odo Ota Local Government areas of Ogun State.

\section{Instrument}

An inventory entitled "Physics teachers' instructional needs inventory" developed by Zurub and Rubba (2003) was adapted for use in this study. It was made up of two sections. Section A sought respondents' personal data, while section B consisted of 20 items on a 4-point scale to which the teachers were required to indicate the extent of their instructional needs in physics: "no help needed", "little help needed", "moderate help needed" and "much help needed". The inventory was pretested on a pilot sample of 30 physics teachers in Abeokuta North and South Local Government Areas. The Cronbach co-efficient value was found to be 0.88 , which reveals that the tool is relevant enough. 


\subsection{Procedure for data collection}

The respective schools were visited by the researcher and the permissions of the school principals were sought. The inventory was given to the respective physics teachers and collected immediately after they were filled in. Then they were scored.

\subsection{Scoring}

The inventory results were manually scored by the researcher. The items were such that a score range of 1 through 4 was assigned to "no help needed" to "much help needed". The maximum obtained score was 80 while the minimum one was 20.

\section{Results}

\section{Research Question 1}

1. What are the instructional needs of physics teachers in the teaching of physics?

Table 1: Frequency distribution of the perceived instructional needs of physics teachers

\begin{tabular}{|c|c|c|c|c|c|c|c|c|}
\hline & Items & $\begin{array}{l}\text { Much } \\
\text { Help } \\
\text { Need } \\
\text { (\%) }\end{array}$ & $\begin{array}{l}\text { Moderate } \\
\text { Help } \\
\text { Needed } \\
\text { (\%) }\end{array}$ & $\begin{array}{l}\text { Little } \\
\text { Help } \\
\text { Needed } \\
\text { (\%) }\end{array}$ & $\begin{array}{l}\text { No } \\
\text { Help } \\
\text { Needed } \\
\text { (\%) }\end{array}$ & Mean & $\begin{array}{l}\text { Standard } \\
\text { Deviation }\end{array}$ & Remark \\
\hline 1. & $\begin{array}{l}\text { Developing questions that demand } \\
\text { higher-order thinking skills }\end{array}$ & 52.5 & 8.7 & 25.0 & 13.8 & 3.00 & 1.16 & MHN \\
\hline 2. & $\begin{array}{l}\text { Harnessing students' existing ideas and } \\
\text { conceptions }\end{array}$ & 45.0 & 21.3 & 7.5 & 26.3 & 2.85 & 1.25 & MHN \\
\hline 3. & $\begin{array}{l}\text { Encouraging students' participation in } \\
\text { classroom lessons }\end{array}$ & 38.8 & 22.5 & 12.5 & 26.2 & 2.74 & 1.23 & MHN \\
\hline 4. & $\begin{array}{l}\text { Connecting science concepts to real- } \\
\text { life examples }\end{array}$ & 34.4 & 12.5 & 17.5 & 16.3 & 3.04 & 1.17 & MHN \\
\hline 5. & $\begin{array}{l}\text { Conceptual understanding of physics } \\
\text { concepts }\end{array}$ & 35 & 23.8 & 12.5 & 23.0 & 2.84 & 1.20 & MHN \\
\hline 6. & $\begin{array}{l}\text { Adapting teaching methods to meet } \\
\text { individual students' needs }\end{array}$ & 37.5 & 22.5 & 16.3 & 23.8 & 2.74 & 1.20 & MHN \\
\hline 7. & $\begin{array}{l}\text { Measuring students' conceptual } \\
\text { understanding }\end{array}$ & 28.8 & 12.5 & 21.3 & 37.5 & 2.33 & 1.25 & LHN \\
\hline
\end{tabular}




\begin{tabular}{|c|c|c|c|c|c|c|c|c|}
\hline 8. & $\begin{array}{l}\text { Linking students' ideas, values and } \\
\text { beliefs to their classroom experiences }\end{array}$ & 45.0 & 12.5 & 15.0 & 27.5 & 2.75 & 1.29 & MHN \\
\hline 9. & $\begin{array}{l}\text { Engaging students in problem-solving } \\
\text { activities }\end{array}$ & 35.0 & 25.0 & 18.8 & 21.3 & 2.71 & 1.17 & MHN \\
\hline 10 & $\begin{array}{l}\text { Helping students' to interact actively } \\
\text { with learning materials }\end{array}$ & 21.3 & 22.5 & 31.3 & 25.0 & 2.40 & 1.09 & LHN \\
\hline 1. & $\begin{array}{l}\text { Creating innovative ideas that can } \\
\text { foster learning }\end{array}$ & 40.0 & 20.0 & 16.3 & 23.8 & 2.75 & 1.23 & MHN \\
\hline 1. & Improvising instructional materials & 37.5 & 23.8 & 13.8 & 25.0 & 2.80 & 1.18 & MHN \\
\hline 1. & $\begin{array}{l}\text { Helping students to ask questions and } \\
\text { discuss their learning experiences }\end{array}$ & 40.0 & 22.5 & 15.0 & 22.5 & 2.89 & 1.14 & MHN \\
\hline 1. & $\begin{array}{l}\text { Using technology to enhance } \\
\text { classroom experiences }\end{array}$ & 23.8 & 17.5 & 25.0 & 33.8 & 2.34 & 1.16 & LHN \\
\hline 1. & $\begin{array}{l}\text { Presenting science experiences as } \\
\text { enjoyable, interesting and relevant }\end{array}$ & 37.5 & 18.8 & 17.5 & 26.3 & 2.68 & 1.23 & MHN \\
\hline 10 & $\begin{array}{l}\text { Assisting students to formulate their } \\
\text { own questions }\end{array}$ & 22.5 & 15.0 & 30.0 & 32.5 & 2.25 & 1.11 & LHN \\
\hline 1. & $\begin{array}{l}\text { Helping students to plan and carry out } \\
\text { investigations in the laboratory }\end{array}$ & 35.0 & 27.5 & 25.3 & 16.3 & 2.83 & 1.06 & MHN \\
\hline 18 & Evaluating students' learning & 35.0 & 17.5 & 12.0 & 26.0 & 2.50 & 1.29 & LHN \\
\hline 19 & $\begin{array}{l}\text { Helping students to connect practical } \\
\text { with underlying theoretical concepts }\end{array}$ & 26.3 & 13.8 & 22.5 & 37.5 & 2.29 & 1.22 & LHN \\
\hline 20 & Teaching science process skills & 41.3 & 25.0 & 20.0 & 13.8 & 2.96 & 1.06 & MHN \\
\hline
\end{tabular}

* MHN - more help needed

* LHN - little help needed

From the analysis on Table 1, having calculated the average mean to be 2.69 , items with means above this value clearly show that much help is needed by the physics teachers. Hence, the teachers need help in developing questions that demand higher order thinking skills $(X=3.00)$; harnessing students' existing ideas and conceptions $(X=2.85)$; encouraging students participation in classroom lessons $(X=2.74)$; connecting science concepts to real life examples $(X=3.04)$; conceptual understanding of physics 
concepts ( $X=2.84)$; adapting teaching methods to meet individuals student's needs $(X=2.74)$; linking students' ideas, values and beliefs to their classroom experiences $(X=2.75)$; engaging students in problem-solving activities $(X=2.75)$; creating innovative ideas that can foster learning $(X=2.75)$; improvising instructional materials $(X=2.80)$; helping students to ask questions and discuss their learning experiences $(X=2.89)$; presenting science experiences as enjoyable, interesting and relevant ( $X=2.68$ ); helping students to plan and carry out investigation in the laboratory $(X=2.83)$; helping students to learn by discovery $(X=2.29)$; teaching science process skills $(X=2.96)$. However, teachers need little help in getting the following teaching activities done: measuring students' conceptual understanding $(X=2.33)$; helping students' to interact actively with learning materials $(X=2.40)$; using technology to enhance classroom experiences $(X=2.34)$; assisting students to formulate their own questions $(X=2.25)$; evaluating students' learning $(X=2.50)$; helping students to connect practical with underlying theoretical concepts $(X=2.29)$.

\section{Research Hypotheses:}

Hypothesis $1\left(\mathbf{H}_{\mathbf{0}} \mathbf{1}\right)$ : There is no significant gender difference in the perceived instructional needs of physics teachers in the teaching of physics and physics practical.

Table 2: Gender difference in the perceived instructional needs of Physics Teachers.

\begin{tabular}{|l|l|l|l|l|l|l|l|}
\hline Teacher's Gender & $\mathrm{N}$ & $\mathrm{X}$ & $\mathrm{SD}$ & $\mathrm{Df}$ & $\mathrm{t}$ & $\mathrm{Sig}$. & Remark \\
\hline Male & 48 & 51.15 & 22.55 & 78 & 1.21 & 0.23 & Not Sig. \\
\hline Female & 32 & 57.44 & 23.20 & & & & \\
\hline Total & 80 & & & & & & \\
\hline
\end{tabular}

The result in Table 2 revealed a non-significant outcome $(t=1.21, p>0.05)$. This outcome implies that the sampled male and female physics teachers did not significantly differ in their perception of instructional needs. The mean score of female teachers (57.44) is higher than that of male teachers (51.15), but the difference is not statistically significant. Hence, hypothesis $1\left(\mathrm{H}_{0} 1\right)$ was not rejected. By implication, there is no significant gender difference in the perceived instructional needs of physics teachers.

Hypothesis ( $\left.\mathbf{H}_{02}\right)$ : There is no significant difference between the perceived instructional needs of more experienced and less experienced physics teachers.

Table 3: Difference in physics teachers' instructional needs by experience

\begin{tabular}{|l|l|l|l|l|l|l|l|}
\hline Teacher's Experience & $\mathrm{N}$ & $\mathrm{X}$ & $\mathrm{SD}$ & $\mathrm{Df}$ & $\mathrm{t}$ & Sig. & Remark \\
\hline Less Exp. & 16 & 53.63 & 22.64 & 78 & 0.17 & 0.99 & Not Sig. \\
\hline More Exp. & 64 & 53.67 & 23.12 & & & & \\
\hline Total & 80 & & & & & & \\
\hline
\end{tabular}


The result in Table 2 revealed a non-significant outcome ( $t=0.17, p>0.05)$. This outcome implies that the sampled physics teachers' instructional needs did not significantly differ with respect to their experience. The mean score of more experienced physics teachers (53.67) is higher than that of less experienced teachers (53.63), but the difference is not statistically significant. Hence, hypothesis $2\left(\mathrm{H}_{0} 2\right)$, was not rejected. By implication, there is no significant difference between the perceived instructional needs of more experienced and less experienced physics teachers.

Hypothesis $\mathbf{3}\left(\mathbf{H}_{\mathbf{0}} \mathbf{3}\right)$ : There is no significant difference between the perceived instructional needs of professional (qualified) and non-professional (not qualified) physics teachers.

Table 3: Difference in physics teachers' instructional needs by professionalism (qualification)

\begin{tabular}{|l|l|l|l|l|l|l|l|}
\hline Teachers' Qualification & $\mathrm{N}$ & $\mathrm{X}$ & $\mathrm{SD}$ & $\mathrm{Df}$ & $\mathrm{t}$ & $\mathrm{Sig}$ & Remark \\
\hline Professional & 69 & 55.23 & 22.61 & 78 & 1.55 & 0.13 & Not Sig. \\
\hline Non-professional & 11 & 43.83 & 23.16 & & & & \\
\hline Total & 80 & & & & & & \\
\hline
\end{tabular}

The result in Table 3 revealed a non-significant outcome $(t=1.55, p>0.05)$. This outcome implies that the sampled physics teachers did not significantly differ in their perception of instructional needs with respect to their professionalism. The mean score of professional physics teachers (55.23) is higher than that of non-professional physics teachers (43.83), but the difference is not statistically significant. Hence, hypothesis $3\left(\mathrm{H}_{0} 3\right)$ was not rejected. By implication, there is no significant difference between the perceived instructional needs of professional (qualified) and non-professional (not qualified) physics teachers.

\section{Discussion}

The findings of this study clearly show that physics teachers' needs vary widely from an array of pedagogical skills and processes such as presenting science experiences as enjoyable, interesting and relevant, adapting teaching methods to meet individual student's needs to developing questions that demand higher-order thinking skills. This finding was supported by the submissions of Ball \& Forzani (2009) and Bryk et.al. (2010). They are of the opinion that teachers need an approach to inquiry-based science teaching to apply well-defined and well-structured opportunities and new learning through analysis involving performance-based assignments. The National Science Board (2010) in the United States equally agrees that science teachers need help with basic understandings and teaching approaches on a wide range of topics. Addressing their needs will necessitate regular in-service training programmes for science teachers updating them with pedagogical skills and introducing novelties to the field of teaching science.

The need indicated by teachers as regards adapting teaching methods to meet individual student's needs necessitate that the teaching method required by teachers must be 'adaptive', that is, teachers must learn how to adapt their methods and strategies to their learners. On this, Ericsson et al. (2007) posited that teachers should do away with the conventional methods, but develop flexible methods and the ability to draw on knowledge in order to invent new procedures for solving unique problems, rather than simply applying already mastered procedures. They should keep upgrading their competence through experiencebased learning. Heller et al. (2012) is of the view that teachers should adapt their practices to all learners. Students have individual 
differences and different styles of breaking a stimulus configuration into its component parts. Some of them are analytic learners, while some are synthetic. In other words, some have a better understanding of a concepts when presented with real objects while some are good in abstraction. A teacher should endeavour to understand each student and adapt the learner to meet individual needs. Having a thorough grasp of the content to be taught in physics is very imperative for physics teachers. In fact, teachers in this study indicated that they need much help in this respect. This view was strongly supported by Ball \& Forzani (2009) who equally share the view that teachers should possess good content knowledge of the subject. Teachers' content competence in physics necessitates that they assume personal responsibility for their growth and development in physics. They have to master the subject and improve the quality of their teaching so as to impact their students efficiently. Mastery of physics requires from a teacher to possess a lot of knowledge in physics above the threshold. This may even involve getting a degree in physics and studying it continuously so as to keep abreast of information and development in physics. It is a known fact that students know and respect teachers who are competent and they tend to listen more to their teaching and invariably learn more and perform better. Such a teacher will exhibit confidence when teaching and gain students' respect. He will be able to connect science concepts to real-life examples, link students' ideas, values and beliefs to their classroom experiences and help them to ask questions and discuss their learning experiences.

\subsection{Conclusion \& suggestions for further studies}

This study has clearly shown the perceived instructional needs of physics teachers concerning teaching physics in senior secondary schools in Ogun State, Nigeria. It revealed where much help is needed and where little help is needed. There is need for regular training for science teachers to cater for their instructional needs. The trainings will keep the teachers abreast of further teaching requirements needed on the job in order for them to become more efficient and effective physics teachers. This study also revealed that the perceived instructional needs of physics teachers was not related to their gender, experience and professionalism.

\section{References}

Aina, J.K. \& Akintunde, Z.T. (2013). Analysis of gender performance in physics colleges of education, Nigeria. Journal of Education and Practice. 4(6), 100-105.

Apata, F.S. (2007). Influence of teachers' academic qualification and experience on students' performance in senior secondary school Physics in Kwara state. Unpublished masters' thesis. Ilorin, Nigeria: University of Ilorin.

Ajileye, O.O. (2006). Towards effective science education: Issues in universal basic education programme. Journal of Sports Management and Educational Research. 1 (2), 337.

Ball, D.L. \& Forzani, F. (2009). The work of teaching and the challenge for teacher education. Journal of Teacher Education, 60(5), 497-511.

Bryk A., Sebring, P., Allensworth, E., Suppescu, S., \& Easton, J. (2010). Organizing Schools for Improvement: Lessons from Chicago. Chicago, IL, USA: The University of Chicago Press.

Ericsson, K.A., Nandagopal, K., \& Roring, R.W. (2009). Towards a science of exceptional achievement: Attaining superior performance through deliberate practice. Annals of New York Academy of Science, 1172, 199-217.

Federal Government of Nigeria (2014). National Policy on Education. Lagos. NERDC. 
Heller, J.I., Daehler, K.R., Wong, N., Shinohara, M., \& Miratrix, L.W. (2012). Differential effects of three development models on teacher knowledge and student achievement in elementary science. Journal of Research in Science teaching, 49(3), 333-362.

National Science Board (2010). Science and Engineering Indicators. Washington, D.C.: National Science Foundation.

Okafor, O.O. (2007). The challenges of effective science teaching in Nigerian secondary schools. Journal of International Proceedings of Social and Behavioural Science, 1(1), 152-159.

Oludipe, B.D. (2008). Impact of Reciprocal Peer-Tutoring on Secondary School Students' Achievement in Large Physics Classes in Nigeria. Ubiquitous Learning, An International Journal. A publication of the University of Illinois, USA, 1(2), 13-18.

Oludipe, B.D. (2009). Influence of early literacy parental involvement on Science achievement of Junior Secondary School students in Nigeria. Ethiopian Journal of Education and Sciences. A publication of the College of Natural Sciences, Jimma University, Ethiopia. 5(1), 93-105.

Oludipe, B.D. (2013): Internal versus external control of reinforcement; where do Nigeria science students belong? Journal of Education and Practice. A publication of the International Institute for Science, Technology \& Education (IISTE), 4(9), 6570.

Snow-Renner, R. \& Lavier, P.A. (2005). Professional Development Analysis. Denver: C.O.McREL.

Wenglinsky, H. \& Silverstein, S.C. (2006). The science training teachers need. Educational Leadership, 64(4), 24-29.

Zurub, A.R. \& Rubba, P.A. (2003). Development and validation of an inventory to assess science teacher needs in developing countries. Journal of Research in Science Teaching. 20(9), 867-873. 